\title{
Viability of fibroblast cells on the clove (Syzygium aromaticum) leaves ethanol extract
}

\author{
Anindhita Cindy Felicia ${ }^{1}$, Natallia Pranata ${ }^{1}$, Vinna Kurniawati Sugiaman ${ }^{1 *}$ \\ ${ }^{1}$ Department of Oral Biology, Faculty of Dentistry Maranatha Christian University, Indonesia
}

\begin{abstract}
Introduction: Various active compounds of herbal plants that are known to accelerate the wound healing process are flavonoids, tannins, and saponins. One amongst them is clove (Syzygium aromaticum), with the leaves as the most common part to be used as herbal medicine due to the antibacterial, antiinflammatory, and antioxidant properties. However, the use of the biocompatibility of clove leaves as herbal medicine is still unknown. Therefore, this study was aimed to determine the cytotoxicity effects of clove leaves ethanol extract on the fibroblast cells and safe dosage $\left(\mathrm{IC}_{50}\right)$ for medicinal use. Methods: Phytochemical tests using the Farnsworth method and viability test was performed using the laboratory experimental with post-test only control group design. The samples were divided into seven concentrations; $500,250,125,62.5,31.25,15.63$, and $7.81 \mu \mathrm{g} / \mathrm{ml}$, with three repetitions (triplo) towards the fibroblast cells. Viability test was performed using MTS assay. Results: Based on the results obtained from one-way ANOVA statistical test, there was a significant difference between the percentage of cell viability and each concentration $(\mathrm{a} \leq 0.05)$, with $\mathrm{IC}_{50}$ value of $344.814 \mu \mathrm{g} / \mathrm{ml}$. Conclusion: Clove (Syzygium aromaticum) leaves ethanol extract showed a high percentage of cell viability at the concentrations below the $\mathrm{IC}_{50}$ value.
\end{abstract}

Keywords: Clove leaves, cytotoxicity, fibroblast cell, MTS assay, periodontal diseases, viability.

p-ISSN: 1979-0201; e-ISSN 2549-6212; Available from: http://jurnal.unpad.ac.id/pid/article/view/21236

DOI: 10.24198/pid.vol30no3.21236

Submission: May 04, 2018; Accepted: Mar 08, 2019; Published online: Mar 31, 2019

\section{INTRODUCTION}

The use of herbs can help cure various kinds of diseases, including diseases in the oral cavity. One of the most common oral diseases in the world (reaching $50 \%$ of the adult population) is periodontal disease. ${ }^{1,2}$

There are many herbs that have not been standardised on the healing treatment. Various active compounds of herbal plants that are known to accelerate the wound healing process are flavonoids, tannins, and saponins. These active substances are mostly found in clove leaves. Flavonoid compounds in cloves have an antiinflammatory effect, able to inhibit free radicals, and slow down the tissue death. Also, there are many eugenol compounds in cloves which have antibacterial and antioxidant effects. ${ }^{3,4}$ 
Therefore, clove (Syzygium aromaticum) leaves have the potential to be used as an alternative medicine for healing in the oral cavity. But now, there is no research about standardisation of the use of clove leaves as an alternative treatment of dental and oral diseases. So it is necessary to conduct a series of studies to standardise the use of clove leaves with the first step, which is carried out research to determine the inhibition concentration $\left(\mathrm{IC}_{50}\right)$ value of clove leaves ethanol extract. This study was aimed to determine the cytotoxicity effects of clove leaves ethanol extract on the fibroblast cells and safe dosage $\left(\mathrm{IC}_{50}\right)$ for medicinal use.

\section{METHODS}

This research was an experimental laboratory study, where each concentration of clove leaves ethanol extract was applied with $3 \mathrm{~T} 3 \mathrm{Balb} / \mathrm{C}$ fibroblast cell culture, then cell viability was determined using MTS (Methyl Thiazol Sulfofenyl) assay in three repetitions (triplo). The control group in this research was unapplied fibroblast cells.

Clove leaves were taken from a 19-yearsold clove plant from Cimenyan Sub-district, Bandung District West Java-Indonesia. The plant was identified at the School of Technology and Biology of Bandung Institute of Technology. The clove leaves were processed into crude extract ${ }^{5,6}$ at the Aretha Medika Utama Biomolecular and Biomedical Research Center.

The phytochemical analysis of crude extract was carried out using the Farnsworth method. The positive results were obtained from flavonoids, tannins, saponins, phenols, steroids, terpenoids, and alkaloids as described below.

Flavonoids identification was performed by firstly added clove leaves ethanol extract ( 10 $\mathrm{mg}$ ) into a test tube, then added with $\mathrm{Mg} / \mathrm{Zn}$, then heated for 5 to $10 \mathrm{~min}$ in the water with the temperature of $87^{\circ} \mathrm{C}$. Cooled it down and filtered, and then $1 \mathrm{ml}$ amyl alcohol was added into it. The positive reaction was shown by the formation of red or orange colour.

Saponins identification was performed by putting the clove leaves ethanol extract $(10 \mathrm{mg})$ into the test tube then boiled in the water for $5 \mathrm{~min}$. Then the solution was shaken vertically for $10 \mathrm{sec}$ and added $1 \mathrm{~N} \mathrm{HCl}$. Saponins content was indicated by the persistence of froth on the surface.

Phenols identification was performed by placing the clove leaves ethanol extract $(10 \mathrm{mg})$ on a dropping plate, then dissolved with $5 \mathrm{ml} \mathrm{ddH} 2 \mathrm{O}$ and added $500 \mu \mathrm{FeCl}_{3} 1 \%$. The presence of phenols indicated by green/red/purple/blue/black colour formation.

Tannins identification was performed by adding the clove leaves ethanol extract $(10 \mathrm{mg})$ with $2 \mathrm{~mL}$ of $\mathrm{HCl} 2 \mathrm{~N}$ in the test tube, then heated on the water for $30 \mathrm{~min}$. The mixture was cooled down and filtered, then the filtrate was added with amyl alcohol. Purple colour formation indicates a positive reaction for tannins.

Steroids/triterpenoids identification was performed by firstly placed the clove leaves ethanol extract $(10 \mathrm{mg})$ on a dropping plate and then immersed with acetate acid until the sample was covered. One drop of absolute sulphate acid $\left(\mathrm{H}_{2} \mathrm{SO}_{4}\right)$ was added to the sample after $10-15$ $\mathrm{min}$. The green/blue colour formation showed the presence of steroids, while red/orange sediment indicates the presence of triterpenoids.

Alkaloids identification was performed by firstly added the clove leaves ethanol extract (10 $\mathrm{mg}$ ) into a test tube, then dissolved with $5 \mathrm{ml}$ of $\mathrm{ddH}_{2} \mathrm{O}$ and steam in the water. The residue was dissolved with $5 \mathrm{ml} \mathrm{HCL} 2 \mathrm{~N}$. The solution obtained was divided into 2 test tubes. The first tube was added 3 drops of HCL $2 \mathrm{~N}$ which functioned as blank, while the second tube was inserted a drop. Three drops of Dragendorff reagent was added afterwards. The presence of orange colour indicated the positive result in the second tube.

Terpenoids identification was performed by adding the clove leaves ethanol extract $(10 \mathrm{mg})$ into a dropping plate, then vanillin and $\mathrm{H}_{2} \mathrm{SO}_{4}$ was added into the sample. Formation of purple colour on the mixture showed the presence of terpenoid content.

The clove leaves ethanol extract was diluted as follows, $5 \mathrm{mg}$ extract (paste preparations) dissolved in $1 \mathrm{ml}$ of $10 \%$ DMSO, resulting in a stock with concentration of $500 \mu \mathrm{g} / \mathrm{ml}$, and then continued with dilutions concentrations of 250 , $125,62.5,31.25,15,625$, and $7.8125 \mu \mathrm{g} / \mathrm{ml}$.

MTS or Methyl Thiazol Sulfofenyl [ 3 - ( 4, 5 - dime thylthiazol- 2 - il ) - 5 - ( 3 carboxymethoxyphenyl)-2-(4-sulfophenyl)-2H- 
tetrozolium] assay was one test of cell proliferation through the measurement of cell viability. The purpose of this test was to determine the toxic effect of material or extract directly on the cell in vitro.

The $3 \mathrm{~T} 3 \mathrm{Balb} / \mathrm{C}$ cells that have been confluent $70-80 \%$ with a density of 5000 cells/ well were plated in 96 well/plates containing Dulbecco's Modified Eagle Medium (DMEM), 10\% Fetal Bovine Serum, and antibiotics-antimycotic (ABAM) 1\%. Then they were incubated at the temperature of $37^{\circ} \mathrm{C}$ with $5 \% \mathrm{CO}_{2}$ for 24 hours. After that, the old medium was replaced with a new medium for each well as $200 \mu \mathrm{l}$ medium and 20 $\mu$ extract, then incubated in the same condition. Furthermore, on each well was added $20 \mu \mathrm{l}$ MTS reagent, and incubated for 3 hours. Then, the absorbance of each well will be measured used spectrophotometer with a wavelength of $490 \mathrm{~nm}$. Cell death was calculated based on cell absorbance and integrated into a standard curve.

The data obtained were processed first through a normality test continued with data analysis with $a=0.05$. The safe dose $\left(\mathrm{IC}_{50}\right)$, the data was processed using the Probit Analysis.

\section{RESULTS}

The phytochemical screening showed the presence of compounds such as flavonoids, saponins, phenols, tannins, steroids, terpenoids, and alkaloids, as shown in Table 1.

\begin{tabular}{|c|c|c|}
\hline No. & Compounds & Result \\
\hline 1 & Flavonoids & $(+)$ \\
\hline 2 & Saponins & $(+)$ \\
\hline 3 & Phenols & $(+)$ \\
\hline 4 & Tannins & $(+)$ \\
\hline 5 & Steroids/Triterpenoids & (+) Steroid \\
\hline 6 & Terpenoids & $(+)$ \\
\hline 7 & Alkaloids & $(+)$ \\
\hline
\end{tabular}

The viability test on fibroblast cells resulted in the percentage of cell viability of each concentration obtained with one-way ANOVA, as shown in the following table and graph.

The highest percentage of cell viability was found in the treatment group with the concentration of $7.813 \mu \mathrm{g} / \mathrm{ml}$, while the lowest was found in the concentration of $500 \mu \mathrm{g} / \mathrm{ml}$.

Table 2. Viability of 3 T3 Balb/C cells after applied with clove leaves ethanol extract

\begin{tabular}{|c|c|c|c|c|c|c|c|}
\hline Sample & $\begin{array}{l}\text { Working } \\
\text { concentration } \\
(\mu \mathrm{g} / \mathrm{ml})\end{array}$ & $\begin{array}{l}\text { Final } \\
\text { concentration } \\
(\mu \mathrm{g} / \mathrm{ml})\end{array}$ & $x$ & $\mathrm{XK}$ & $\begin{array}{l}\text { Number of } \\
\text { viable cells }\end{array}$ & $\begin{array}{l}\text { Viability } \\
\text { (\%) }\end{array}$ & $\begin{array}{c}\text { Inhibition } \\
\text { (\%) }\end{array}$ \\
\hline \multicolumn{3}{|l|}{ Cell control } & 2.0389 & 1.4510 & 100.00 & 0.00 & 5000 \\
\hline \multicolumn{3}{|c|}{ DMSO $10 \%$ control } & 1.9397 & 1.4108 & 97.23 & 2.77 & 4862 \\
\hline \multirow{7}{*}{$\begin{array}{l}\text { Clove leaves } \\
\text { ethanol } \\
\text { extract }\end{array}$} & 5000 & 500 & 2.5764 & 0.5811 & 2003 & 40.05 & 59.95 \\
\hline & 2500 & 250 & 2.4566 & 0.8773 & 3023 & 60.46 & 39.54 \\
\hline & 1250 & 125 & 2.4485 & 0.9635 & 3320 & 66.40 & 33.60 \\
\hline & 625 & 62.5 & 2.3437 & 1.1749 & 4049 & 80.97 & 19.03 \\
\hline & 312.5 & 31.25 & 2.0492 & 1.2080 & 4163 & 83.26 & 16.74 \\
\hline & 156.25 & 15.63 & 1.9109 & 1.2960 & 4466 & 89.32 & 10.68 \\
\hline & 78.13 & 7.81 & 1.9744 & 1.4120 & 4866 & 97.31 & 2.69 \\
\hline
\end{tabular}

$\mathrm{XK}=$ average absorbance value correction

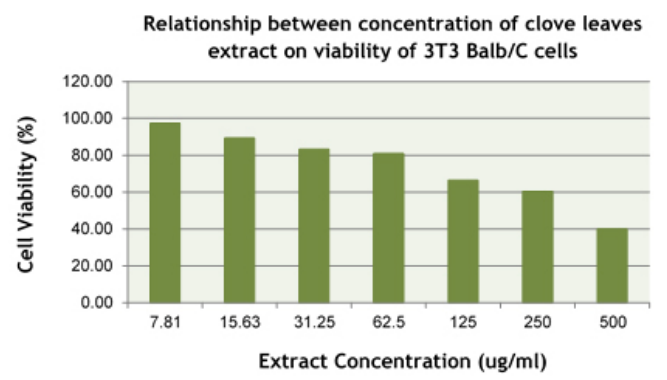

Figure 1. Relationship between clove leaves extract concentration and 3T3 Balb/C cells viability 
Furthermore, the data were analyzed are normally distributed and homogeneous. Almost all groups of extract concentration had significant differences in cell viability $(\mathrm{p}<0.05)$, except in the concentration groups of $62.5 \mu \mathrm{g} / \mathrm{ml}$ and $31.25 \mu \mathrm{g} /$ $\mathrm{ml}$ with $\mathrm{p}>0.05$. Based on the average percentage of cell viability, the inhibition concentration $\left(\mathrm{IC}_{50}\right)$ value was $344.814 \mu \mathrm{g} / \mathrm{ml}$ as seen in Table 3 .

Table 3. Results of Probit analysis of IC value

\begin{tabular}{ccc}
\hline $\mathrm{IC}_{50}$ & Probability & Value \\
\cline { 2 - 3 } value & .500 & 344.814 \\
\hline
\end{tabular}

\section{DISCUSSION}

Clove (Syzygium aromaticum) leaves have chemical properties in the form of flavonoids, saponins, phenols, tannins, steroids, terpenoids, and alkaloids; and also had eugenol, eugenol acetate, and B-caryophyllene which are most abundant in clove leaves essential oil which can be used as a treatment of oral diseases. ${ }^{7,8}$

Development of herbal medicinal materials for the prevention and treatment of oral diseases, it is necessary to test biocompatibility by the material requirements in dentistry. One of the biocompatibility tests that can be done is the viability test to obtain a safe dose ( $\mathrm{IC}_{50}$ value) from the use of the material. Viability tests were carried out on ethanol extracts of clove (Syzygium aromaticum) leaves on fibroblast cells that could help the healing process using MTS assay.

MTS assay is a new type of tetrazolium salt, which can be reduced by viable cells to form formazan products which are immediately soluble in cell culture media. This test shows the ability of viable cells to reduce purple salts and dissolve into formazan products and then measured using a spectrophotometer with a wavelength of $490 \mathrm{~nm}$. The absorbance value will be directly proportional to the number of viable cells and will decrease with increasing concentration of the material used. Therefore, cells that cannot be measured for absorbance are dead cells because they are unable to convert MTS compounds to formazan salts.

Clove leaves ethanol extract has several active compounds as flavonoid, tannins, and saponins, which play an important role to help the tissue healing. Flavonoids are also known as potent inhibitors of several enzymes, such as xanthine oxidase (XO), phosphoinositide 3-kinase, cyclooxygenase (COX), and lipoxygenase which have important roles as inflammatory mediators. The anti-inflammatory effect of flavonoids will trigger the work of neutrophils containing lipoxygenase which produce chemotaxis compounds from arachidonic acid to release cytokines. Phenolic compounds can inhibit the cyclooxygenase and 5-lipoxygenase pathways. Also, quercetin can inhibit the activity of these two pathways by reducing the formation of inflammatory metabolites. Flavonoids also inhibit neutrophil degranulation in tyrosine 3-monooxygenase kinase to reduce the release of arachidonic acid. ${ }^{9}$ Flavonoids containing free hydroxyl groups on their aromatic rings have free radical capture activity. The action of flavonoids includes reducing free radicals, suppressing enzymes associated with free radicals, and stimulating internal antioxidant enzymes. ${ }^{10}$

Tannins are also known as scavenging free radicals because it has astringent and antimicrobial effects. Also, tannins can help the process of tissue healing through increased fibroblast cell proliferation and formation of capillary vessels. ${ }^{11,12}$ Saponin is also one of the compounds that can help the tissue healing process because it has antioxidant, antimicrobial, and anti-inflammatory effects through re-epithelialization and inhibition of the initial inflammatory process. Saponins are also responsible for stimulating collagen formation in wound contractions. ${ }^{12,13}$

Cell death or apoptosis is caused by the interaction between cells, and the content of clove leaves ethanol extract. This situation might be caused by the cytotoxic activity of eugenol compounds and phenolic terpenes around $54-73 \%$. Also, eugenol compounds are thought to cause hypersensitivity reactions in the skin. ${ }^{14,15}$ The agents that cause toxicity can be through different mechanisms such as cell membrane destruction, prevention of protein synthesis, irreversible binding of the receptors, inhibition of polydeoxynucleotide elongation, and enzymatic reactions. Apoptosis can occur when cells are exposed to conditions different from their physiological conditions, or there are compounds that damage cell membranes. Apoptosis begins with a disruption in the cell to 
maintain homeostasis, thereby causing water and extracellular ions to enter the cell. Intracellular organelles, such as mitochondria, will swell and rupture (cell lysis). Besides, factors that may play a role in the toxicity of a substance are the exposure time and the toxicity mechanism of the compound. ${ }^{16,17}$

The results of the viability test of clove leaves ethanol extract against fibroblast cells showed that the lower of the extract concentration, the higher cell viability. The half-maximal inhibitory concentration $\left(\mathrm{IC}_{50}\right)$ was analysed to determine the level inhibition of material with various concentrations of $50 \%$ cells so that further tests such as $\mathrm{ED}_{50}$ and $\mathrm{LD}_{50}$ on clove leaves ethanol extract can be carried out. The $\mathrm{IC}_{50}$ values from this study indicate that there is a high percentage of cell viability at concentrations of 250,125 , $62.5,31.25,15.63$, and $7.81 \mu \mathrm{g} / \mathrm{ml}$ of clove leaves ethanol extract on $3 \mathrm{~T} 3 \mathrm{Balb} / \mathrm{C}$. The percentage of cell viability from each concentration indicates, the lower the concentration of the extract, the higher the cell viability, so that cells exposed to substances or drugs beyond the peak exposure can cause cell death.

The limitation of this study was only determining the safe dose, and cell viability of the clove leaves ethanol extract. Therefore, it is necessary to conduct further research is needed to determine the proliferative effects of fibroblast cells on the clove leaves ethanol extract.

\section{CONCLUSION}

Clove (Syzygium aromaticum) leaves ethanol extract showed a high percentage of cell viability at the concentrations below the $\mathrm{IC}_{50}$ value.

\section{REFERENCES}

1. Pratiwi EW, Praharani D, Mahdiyah Y. Daya Hambat Ekstrak Daun Pepaya (Carica papaya L.) terhadap Adhesi Bakteri Porphyromonas gingivalis pada Neutrofil. e-Jurnal Pustaka Kesehat. 2015;3(2):193-8.

2. Vargas SAI, Ilyina A, Segura CEP, Silva BY, Méndez GL. Etiology and Microbiology of Periodontal Diseases: A Review. African J Microbiol Res. 2015; 9(48): 2300-6. DOI: 10.5897/AJMR2015.7609
3. Wibowo N., Comariyati N. Pengaruh Olesan Minyak Cengkeh (Syzygium aromaticum) terhadap Proses Penyembuhan Luka Insisi pada Hewan Coba Mencit (mus musculus) strain Balb/ c. J Keperawatan Muhammadiyah. 2017;2(1):1-3.

4. Fatimahtuzzahroh, Firani NK, Kritianto $\mathrm{H}$. Efektifitas Ekstrak Bunga Cengkeh (Syzygium aromaticum) terhadap Jumlah Pembuluh Darah Kapiler pada Proses Penyembuhan Luka Insisi Fase Proliferasi. Maj Kesehat FKUB. 2015;2(2):92-8.

5. Prema R, Sekaran D, Sekar S, Bannoth K, Sekhar C. In vitro Cytotoxicity Study on Combined Plants Extracts (Cissus quadrangularis and Aegle marmelos). Eur J Exp Biol. 2012;2(4):882-8.

6. Kuete V, Fankam AG, Wiench B, Efferth T. Cytotoxicity and Modes of Action of the Methanol Extracts of Six Cameroonian Medicinal Plants against Multidrug-Resistant Tumor Cells. Evidence-Based Complement Altern Med. 2013;2013:1-10.

7. Razafimamonjison $G$, Jahiel $M$, Duclos $T$, Ramanoelina P. Bud, Leaf and Stem Essential Oil Composition of Syzygium aromaticum from Madagascar, Indonesia and Zanzibar. Int J Basic Appl Sci. 2014;3(3):224-33.

8. Vizhi D, Irulandi K, Mehalingam P, Kumar N. In Vitro Antimicrobial Activity and Phytochemical Analysis of Fruits of Syzygium aromaticum (L.) Merr. \& L.M. Perry - An Important Medicinal Plant. J Phytopharm. 2016;5(4):137-40.

9. Wael S, Mahulette F, Watuguly TW, Wahyudi D. Pengaruh Ekstrak Daun Cengkeh (Syzygium aromaticum) terhadap Limfosit dan Makrofag Mencit Balb/C. Tradit Med J. 2018;23(2):7983.

10. Panche AN, Diwan AD, Chandra SR. Flavonoids: An overview. J Nutr Sci. 2016;5:1-15.

11. Szemraj J, Krzyzowska M, Czupryn M, Celichowski G, Zmigrodzka M, Antos-Bielska M, et al. Tannic Acid-modified Silver Nanoparticles for Wound Healing: The Importance of Size. Int J Nanomedicine. 2018; Volume 13:991-1007.

12. Soni $H$, Singhai AK. A Recent Update of Botanicals for Wound Healing Activity. Int Res J Pharm. 2012;3(7):1-7.

13. Kim YS, Cho IH, Jeong MJ, Jeong SJ, Nah SY, Cho YS, et al. Therapeutic Effect of Total 
Ginseng Saponin on Skin Wound Healing. J Ginseng Res. 2011;35(3):360-7.

14. Prashar A, Locke IC, Evans CS. Cytotoxicity of Clove (Syzygium aromaticum) Oil and Its Major Components to Human Skin Cells. Cell Prolif. 2006; 39(4): 241-8. DOI: 10.1111/j.13652184.2006.00384.x

15. Khunkitti W, Veerapan P, Hahnvajanawong C. In Vitro Bioactivities of Clove Buds Oil (Eugenia caryophyllata) and Its Effect on
Dermal Fibroblast. Int J Pharm Pharm Sci. 2012; 4: 3-7.

16. Aslantürk Ö. In Vitro Cytotoxicity and Cell Viability Assays: Principles, Advantages, and Disadvantages. In: Genotoxicity - A Predictable Risk to Our Actual World. 2018. p. 1-18.

17. Tonder JJ. Development of an In Vitro Mechanistic Toxicity Screening Model Using Cultured Hepatocytes. UPSpace Institutional Repository. University of Pretoria; 2011. 